This is an electronic reprint of the original article. This reprint may differ from the original in pagination and typographic detail.

Author(s): Ilmonen, Kari

Title: $\quad$ The Role of Culture in Regional Development Work - Changes and Tensions

Year: $\quad 2015$

Version:

Please cite the original version:

Ilmonen, K. (2015). The Role of Culture in Regional Development Work - Changes and Tensions. In F. M. Go, A. Lemmetyinen, \& U. Hakala (Eds.), Harnessing Place Branding Through Cultural Entrepreneurship (pp. 79-95). Palgrave Macmillan. https://doi.org/10.1057/9781137465160.0013

All material supplied via JYX is protected by copyright and other intellectual property rights, and duplication or sale of all or part of any of the repository collections is not permitted, except that material may be duplicated by you for your research use or educational purposes in electronic or print form. You must obtain permission for any other use. Electronic or print copies may not be offered, whether for sale or otherwise to anyone who is not an authorised user. 


\section{The Role of Culture in Regional Development Work - changes and tensions ${ }^{1}$}

\section{The 'cultural turn' in regional development}

A worldwide trend for the integration of culture into regional development strategies has been taking place from the 1990s onwards, a trend in which towns and cities have adopted culture-led development strategies in the hope of strengthening their competitive position (Miles \& Paddison 2005: 833-839) and culture has even been regarded as a significant resource in village development strategies in China (Oakes 2006: 13-37). The OECD report Culture and Local Development (2005) recommends the strengthening of communities' cultural capital through education and work practice, as this is believed to have a beneficial effect on local and regional development. All this led Radcliffe (2006: 228) to claim that a 'cultural turn' with its attending discourses, paradigms and actors had taking place in development work.

The term 'regional development' is frequently taken to refer to economic, social and ecological development and to imply the conscious and active exercise of influence on the development of a given area or region and its leadership and administration which is assumed to call for a certain kind of regional development knowhow. In the Finnish context culture (including the arts) has been gaining a progressively stronger foothold alongside other aspects of development in the strategies and scenarios espoused by local and regional authorities. One example of the raising of culture to the level of equality with other branches of development can be perceived in the Regional Programme for Central Ostrobothnia, 2007-2010:

"The culture of Central Ostrobothnia is increasingly being viewed as a local, regional, national and international resource, and the exploitation of culture and the arts as a means of creating an image for the region and its economic life and promoting competitiveness is being seen as an important part of the development of well-being in the region and the stimulation of its economic opportunities." (K-Pliitto 2007: 27)

This brief quotation contains many of the terms that lie at the heart of the discourse of regional development: "resource", "exploitation", "economic life", "image", "competitiveness", "well-being" and "promoting". These are instrumental values that are used in many policy documents to bang the drum on behalf of culture and the arts, as in the strategy Cultural Competitiveness and Vitality for Southern Ostrobothnia, where it is observed that

"In the current global pattern of social development, culture is being looked on as a more significant factor in the development of economies and societies than ever before. Where it was previously regarded very much as a value in its own right, it has now become an essential part of regional development, so that cultural development has come to focus on questions of well-being and the making of a living from cultural activities. The significance of culture is now more closely

\footnotetext{
${ }^{1}$ An adapted and extended version of the paper in Finnish Ilmonen (2009) Kulttuurin ja aluekehityksen jännitteet ja mahdollisuudet, with more accent on the critical perspective.
} 
connected with its powerful position as a means of building up an image for a given area or region and strengthening its power of attraction. Culture can also have a beneficial influence on an area by promoting a sense of belonging and enhancing the local identity." (E-P-liitto 2004: 8)

Purontaus (2008: 121) perceives differences in emphasis between the cultural strategies of regional councils and local authorities alongside the assertions of the instrumental value to be attached to culture. The regional strategies in particular tend to start out from the world of EU projects, with its dominant discourses and resources to be tapped - with the underlying question of "How can culture support an area's development?", while the purpose of a town or city in drawing up a cultural strategy is largely to document the justifications for its own aims in view of the competition for resources within the local authority. The same author then goes on to maintain that even though the legitimation of public funding for culture on the grounds of its influence on the area's image and development may be a somewhat vulnerable argument relative to the justifications for more 'concrete' investments: "In an age in which the emphasis is on economic efficiency and profitability, culture is required to demonstrate its significance to the community and to society at large so that it will be regarded as an activity that lends support to competitiveness and productivity in spite of its naturally low profit margins" (Ibid. 122123).

Changes have taken place in the field of cultural policy in Finland and in the other Nordic welfare states towards more market-oriented ways of speaking that emphasize the economic use to be derived from culture (see Ahponen 1991; Heiskanen 1994; Luttinen 1997; Ilmonen 1998; Kangas 2004; Häyrynen 2006), so that these can be more readily accepted as natural and favoured forms of expression within the linguistic framework of regional development. In simplified terms one might say that the dominant discourses and actors in regional development and cultural policy have begun to merge together to a deeper extent, a trend that has the effect of instrumentalizing the field of the arts and neoliberalizing the welfare state, as claimed in the criticism put forward by Paola Merli (2002) and Eleanora Belfiore (2003), for example. The hegemony of the administrative processes involved has nevertheless pushed such marginal, heretical voices out of range.

Although the ways of speaking in the fields of culture, economics and administration have been tuned to represent a single, consistent strategic language, it is quite another question whether the regional strategies have been successfully transformed into action, social processes and structures, or whether they have produced any obvious benefits at all for the people and communities of their areas. Many of the strategies have become ancient monuments buried in filing cabinets or, as Häyrynen (2006: 127) describes them, they were no more than decorative promises and expressions of rhetorical nihilism from the outset. This led Purontaus (2008) to comment that "if they wish to combat cynicism and antidevelopmental attitudes, public sector organizations should not draw up strategies unless they have the resources with which to put them into effect and a real interest in doing so." Mistakes of this kind were made in abundance during the recession years of the 1990s, when culture-based image campaigns gained a fashionable status in the administrative systems of regional councils and local authorities.

When setting out to evaluate the local or regional impact of culture and the arts, attention must also be paid to processes of the kind referred to as 'emergent development', i.e. spontaneous trends that may be partly unconscious in nature and obey laws of their own, 
which are extremely difficult to detect and study (see Sotarauta \& Kosonen 2004: 25). Not all activity can be examined or initiated via systematic governance or administration.

Also, the deeper one goes in the direction of the creative or performing arts (see Loisa 2004: 165), the more conflicts of values and cultural struggles may be focused on these in the context of administrative strategies or image campaigns, since the opposition between instrumentality and autonomy is a deep-seated one. On the other hand, dichotomies involving conflicting values will scarcely arise in the case of popular culture or cultural entrepreneurship because the logic of a culture industry that provides people with a living has always functioned on market principles.

If one was to ask the actress and theatrical director Leea Klemola for her opinion on regional development, for instance, she would probably massacre the concept at the outset, causing mild astonishment in futures workshops arranged in connection with regional planning and related programmes, where the discourse of development flows pleasantly as a self-evident theme that is not even questioned. And she would raise her anarchistic tone still further if culture and the arts appeared to occupy a natural place in the vocabulary of regional development. Indeed, a critical commentator might well brand the development discourse as purely a question of power, as a part of post-Second World War western modernization and the subjugation of "underdeveloped" areas (the Third World, development regions and rural areas) to the categorizations and strategies generated by the majority culture (cf. Escobar 1995).

In general, however, it has been the custom in both the cultural sector and the academic community to put forward positive, constructive arguments for a link between culture and regional development. Much has been written and spoken in recent years about culturally sustainable development, sharpening and advancing the observations and interpretations that have for a long time been associated with the tensions and opportunities existing between culture and developmental work.

\section{Conflicts, or communication on an equal footing?}

Studies of the regional impact and utility of culture and the conclusions reached in them have taken shape mainly according to the research traditions that the scholars concerned have espoused and committed themselves to. It is evident, for instance, that the integrative view of the connection between social capital and development within society as put forward by Robert D. Putnam (1993) would provide a totally different path for such research from the approach based on structuralism and conflict theory as advocated by Pierre Bourdieu (1995), with its emphasis on the inherent struggle between social fields (see Siisiäinen 2003: 204-218). It is probable that the former would lay stress on the opportunities for interaction, mutual trust and balanced regional development, while the latter would set out by emphasizing conflicts of interest and power issues, which admittedly would also serve to carry development forward. As Siisiäinen (Ibid. 215-216) sums up the situation, "A strict commitment to Bourdieu's notion of social capital would lead to a quite different perspective on the same special problems from an adherence to that of Putnam." In spite of this, however, there are many empirical studies of culture in which the methodological perspective has been left entirely on one side, without any conceptualization or discussion. 
When speaking of culture or the arts in connection with regional development, we should similarly not forget the earlier philosophical constructs that could nowadays be looked on as 'historical myths'. The L'art pour l'art (Art for Art's Sake) movement that arose in the 19th century was utterly opposed to the harnessing of art for external purposes and to demands that it should possess a utilitarian value (see Laurila 1947), while the autonomy of art was defended in the 20th century, under the influence of the Frankfurt School, by alluding to its lack of any inherent function and the nature of radical modern art as a denial of the rational society surrounding it (see Adorno 1972). Views of this kind may seem strange and unfashionable nowadays, but it was evidently on the basis of these that critics set out later to question the attempts made to control art and culture, e.g. in connection with the creation of images for localities and regions (see Ilmonen 1994a \& b; also Ilmonen 2003: 17-23).

In the troubled times of the economic recession in the early 1990s the harnessing of culture, and particularly the field of the arts, for the purpose of local and regional imagebuilding strategies was criticized above all by artists themselves, whose views on matters of cultural policy were chiefly grounded in a humanistic concept of art and the ideals of the welfare state, implying that culture and the arts should be assured of their autonomy and of support from society at large without any concrete utilitarian obligations. They were inclined to attach value primarily to the social and intellectual benefits accruing from culture and the arts rather than the regional economic benefits or associated image benefits that were expected in local and regional political and administrative circles in exchange for financial support. On the other hand, some measure of internal competition emerged within the field of the arts, as reflected in the conflict of interests between the predominating cultural system that received support from society, including professional theatres and orchestras, and the marginalized amateur sector, since the former was committed to defending their existing positions and advantages while the latter was demanding a reorganization of the cultural sector and a redistribution of funding and was ready, with certain reservations, to accept market ideals such as the supply and demand principle, image campaigns and cultural tourism (Ilmonen 1994b, 1998). This was an interpretation that relied mainly on Bourdieu's conflict perspective, which is open to criticism on the grounds that it may lead to a paranoiac disregard for certain interesting community initiatives and development paths or cause them to be blocked for considerable lengths of time.

Purontaus (2008) continued research into these same problems in the same locality during the first decade of the 21 st century, but based on a negotiation perspective, asking what kind of interaction arose between the administration and the world of the arts and how joint planning worked out during the process of creating the cultural strategy. The aim of the process as such had been to test the efficacy of multi-party discussions on an equal footing aimed at achieving mutual understanding. Although some of the artists were critical of the competitive and attractional functions assigned to culture by the administrative authorities, preferring to lay emphasis on its social and health-related contributions, a certain movement towards mutual understanding and closer interaction could be detected. This may be attributed at least in part to a change in atmosphere within society and to the action research approach that had been adopted, in accordance with the communicative activity theory of Jürgen Habermas (1981) and with the concrete strategy development efforts made by the researcher. It should also be noted that the researcher was himself a city council official in the cultural sector, whereas Ilmonen had at the time of his research been a member of the city's artistic community. Purontaus came to the conclusion that more 
time in the planning of public sector services should be set aside for listening to the opinions of interested parties and for discussions and negotiations, although the creation of a more open society cannot be expected to be a painless process (Purontaus 2008: 234). Communicative planning has been criticized, among other things, for the fact that the parties to it are only seemingly on an equal footing and that it is impossible to achieve full agreement and genuine understanding (Jauhiainen \& Niemenmaa 2006: 64).

\section{From economics to more open significations of culture}

One international model and source of inspiration for the Finnish researchers who were particularly interested in the economic implications of culture in the early 1990s was the British economist John Myerscough's The Economic Importance of the Arts in Britain (1988). This analysis of the very substantial cash flows generated by the general public and the culture industry within arts organizations also aroused a certain amount of criticism among researchers later, on the grounds that not all the turnover generated by culture remains in the locality or region concerned, as most of it is distributed widely elsewhere (see Ilmonen, Kaipainen \& Tohmo 1995; cf. Cantell 1993). There were also some doubts expressed as to the ability of economists to evaluate the impact of culture successfully (see Rydman \& Sappinen 1988; Valtonen 1992). An empirical assessment of the primary economic impacts of culture, e.g. revenues from theatre ticket sales, together with the secondary impacts, e.g. company incomes and tax revenues derived from a theatrical performance, clearly cannot recognise all aspects of the total impact of culture on a given area (see also Kainulainen 2005).

Further important contributions to the discussion were provided by the reviews of German cultural research results and statements published by the Swedish-German journalist Lisbeth Lindeborg in her Kultur som lokaliseringfaktor and Kulturens betydelse (1991). Alongside the fact that these opinions served to crystallize the adage "Culture is a good economic proposition" in Finland and the world in general, it is clear that Lindeborg wished to emphasize the intellectual and social significance of culture and the effect of major cultural investments in defining the image of a locality or region. Lindeborg encouraged closer partnership between culture and the economic sphere - on condition, of course, that culture was able to preserve its autonomy where content was concerned. In her opinion, society's support for culture could very well be filled out by company sponsorship, as an economically viable cultural life is of benefit in many ways to a locality or region and to its companies and inhabitants. From this ensued another saying that was widely banded about in development strategies and cultural seminars in the 1990s, that "Culture is worth investing in". It was popular to claim, for instance, that every Finnish mark invested in culture would yield a certain number of marks in return.

There were admittedly some cultural economists at that time, such as Georg Arnestad (1992) and Trine Bille Hansen (1993), who regarded the justification of culture purely on local economic grounds as a slightly dangerous pursuit, since it could even damage and constrain opportunities for cultural activities in the long run, e.g. by generating a local or regional cultural policy that would begin to favour only those branches of culture which conspicuously contributed to employment, entrepreneurship and tourism in the area concerned and enhanced its image. This would represent a threat to the cultural democracy and the diversity of cultural services - not to mention the autonomy of the arts. 
The aim of the Nordic research project entitled Kultur og regional udvikling in the early 1990s was to estimate the significance of culture for the sense of community existing among the people in each area, the formation of their cultural identity and the development of the local economy. Particular attention was paid to signs of more determined instrumentalization of culture within development strategies and image campaigns. As market ideals became more firmly rooted in the ways in which people spoke of development, it seemed that the ways of speaking of culture, too, became all the more obviously transformed into discourses of economic profit. Simply the titles of the two reports that emerged from this project, Kulturens spcendetrøje (The Cultural Straightjacket, 1992) and Kulturens brug eller misbrug (Use or Abuse of Culture, 1993), tell us something of the breadth and critical nature of the problems addressed when considering the logic of the harnessing of culture in the service of a local economy and administration. In addition, as least allusions were made to the desirability of a cultural policy of the kind found within the Nordic model of the welfare state, in which society's support and guidance for culture and the arts without undermining their autonomy remains essential, rather than motivating actors within culture and the arts - or forcing them outright - to venture onto the gaming board of market forces and values.

By the turn of the millennium instances within both research and administration were taking it upon themselves to construct a common ground for discourse between culture and the economy in accordance with international trends. Economic creativity, social creativity, well-being and cultural production were the themes that emerged in those discussions (Himanen 2004; Wilenius 2004; Koivunen 2004). Even the report of the Policy Committee for the Arts and Artists (TAO 2002: 16-17) encouraged the integration of culture into administrative strategies and scenarios, stating that "It is to the advantage of the arts, citizens in general and the whole of society that the significance of the arts as a factor in a creative welfare society should be recognised and taken into account better in the decisionmaking processes within society, in the related documents and plans and in resourcing of the arts."

At the same time multidisciplinary cultural studies were beginning to examine preconditions for the success of society and given regions, particularly from the perspectives of economic creativity, the symbolic economy or the culture industry. Greater sensitivity began to be exercised in studying how and on which dimensions the various functions implicated within culture were reflected in regional development, and attention was drawn not only to the primary and secondary economic repercussions of culture in a region but also to its processual and invisible (tertiary) effects. "A hybrid relation prevails between culture, the economy and regional development" was the basic thesis put forward by Kimmo Kainulainen (2005: 437; see also 2004). In his opinion it was difficult, if not impossible, to measure the extent to which these were intertwined, but the resulting dynamic entity could be understood in the form of invisible processes and intersections that manifest themselves as enhancements of a region's non-material and material cultural capital, as if they were forces that nurtured and propelled each other. By non-material capital Kainulainen meant such things as the more creative atmosphere, stronger sense of local identity and higher level of knowhow in the field of culture that could be generated in a given locality by the holding of a cultural festival there, while the material capital referred to structures set up for the purpose of such a festival, including financial resources and organizations supporting it or ancillary to it. 
The empirical cases quoted by Kainulainen in his qualitative study based mainly on discourse analysis were festivals held either in cities or in rural areas, such as the Jyväskylä Festival and the Midnight Sun Film Festival in Sodankylä. His scheme for representing the relationship between the festival gaining roots in the area, the cultural capital generated by it and its positive effect on the image and perceived attractiveness of the area was the following (Ibid. 366):

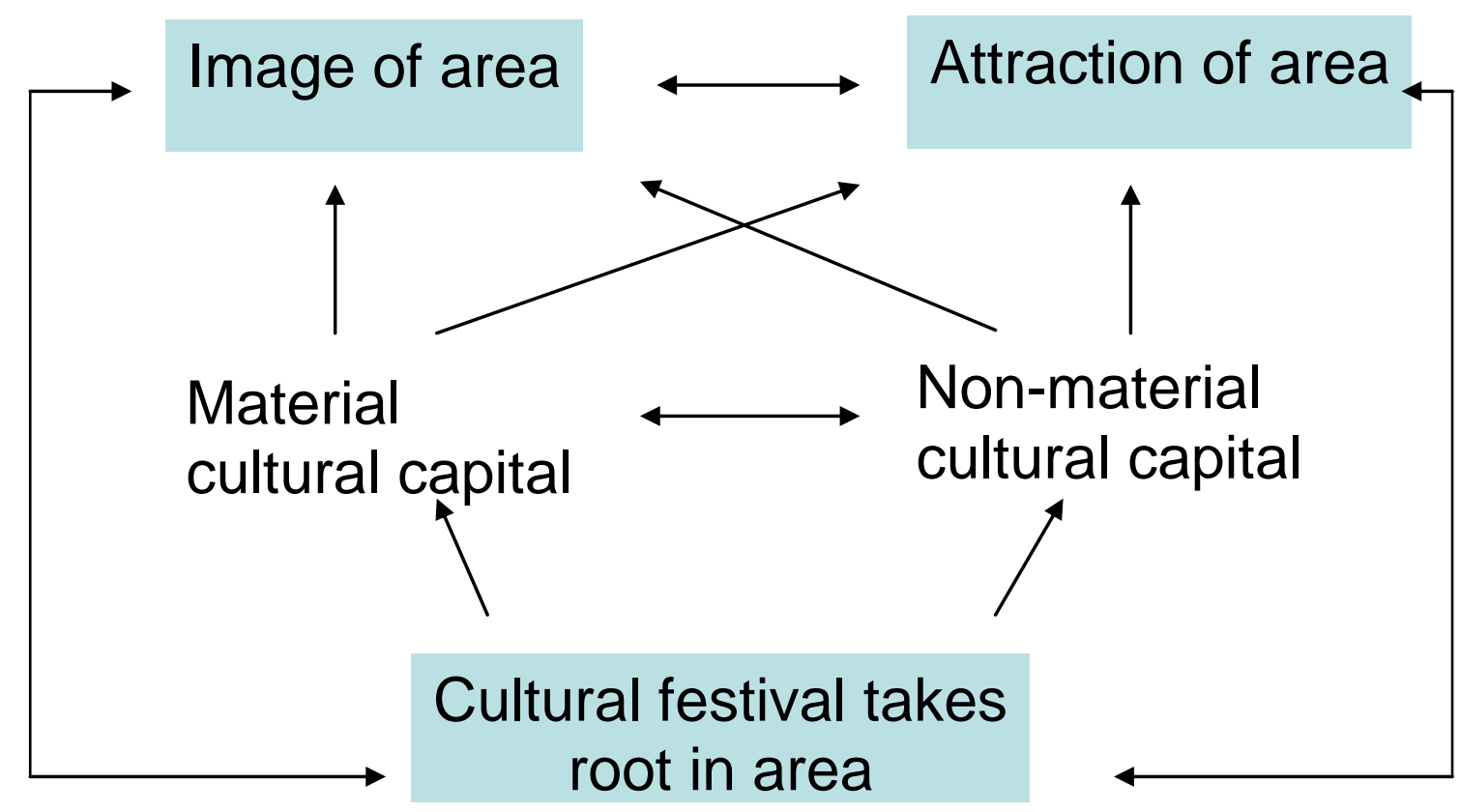

Human geography has also contributed to our understanding of the integration of culture into localities and regions, although the definition of culture is usually broader in this case, covering all symbolic and linguistic interpretations associated with the surface of the Earth. Ilkka Luoto $(2006 ; 2008)$ has been interested in rural localities that have fared substantially better than most, e.g. in terms of demographic or economic development or tourism. One interesting finding was that such localities seemed to stand out from others in having a local spirit that could be confirmed from repeated references in the media. Luoto examined three Finnish localities of this kind and three Scottish ones and considered their core narratives:

- $\quad$ Äkäslompolo $\rightarrow$ narrative of Arctic nature

- Fiskars $\rightarrow$ narrative of an old ironworks taken over by a community of artists and artisans

- $\quad$ Tuuri $\rightarrow$ success story of a local shopkeeper publicized in the media

- Drumnadrochit $\rightarrow$ tale of the mythical Loch Ness Monster

- Dufftown $\rightarrow$ narrative of the art of whisky distilling

- Baile Mór $\rightarrow$ narrative of religious beliefs with mythical elements

According to Luoto (2006), we are living in a new age of stories, with fresh significance attached to the expressiveness of language, an age which has opened up new strategies of visibility and marketing for small, remote places. He applies the term 'neolocality' to the different groups of users, i.e. places that contain and are able to exploit intersecting 
semantic structures and local forms of narratives. The tourist trade has traditionally made use of, and continues to exploit to an increasing extent, the cultural texts that surround certain places, since extended leisure time has allowed people the space to seek more excitement in their lives, and it is characteristic of the age for meanings to be attached to spaces very much through fictive narratives that in turn gain elements from the factual space. In other words, truly interesting places are ones that suitably stimulate the imagination while at the same time being sufficiently real. Luoto points out, however, that the arousing of intensive experiences in observers and the possession of a spirit that is capable of radiating over a considerable distance both call for a historical foundation, a tradition, cultural knowhow and participatory human activity. On the final page of his doctoral thesis Luoto (2008: 224) notes that "The conscious striving after something exciting poses a challenge for rural developers in a moral sense, too. Spectacular performances make for quick publicity, but they do not necessarily contain the ingredients for the long-term development of a sense of place."

\section{Culturally sustainable development}

At a cultural seminar which the author attended in 1990 the social geographer Anssi Paasi gave a paper entitled Culture and Regional Development, in which he stated that if one wished to commercialize regional identities for some purpose such as the promotion of tourism, it would be morally correct "for the image as created and projected to be based on genuine features of the area's natural environment and culture" (Paasi 1990: 46). He also warned that in the heat of commercialization by accentuating some features and excluding others one might very well end up by neglecting the environment that provides the natural source of identity for the area and the local people. He also noted that "local factors represent a more concrete foundation for regional development work as well than do identity clichés applied to whole provinces" (idem.). In fact, the scholars quoted above have clearly observed this ethical principle or come to the same conclusions themselves. The critical attitude towards market forces that prevailed at that time is also evident from the present author's remark:

"When drawing up cultural strategies for municipalities and regions it is also possible to set out from the notion that a social community is an entity structured by its traditions (albeit attenuated and modified in some cases) and its culture. In order to ensure the continuity of these, it is necessary to achieve the broadest possible value and norm-based consensus regarded interpretations of the community's future. ... The images that may emerge from the commonly agreed principles of action and the ensuing creative work would not be reduced to short-term semantic values that can be exchanged indifferently on the open market but would become part of the content of the lives of the community and its individuals and would support their identity." (Ilmonen 1994a: 34-35)

This same issue has more recently been formulated in a somewhat more stringent manner in terms of the concept of 'culturally sustainable development', an application and contributory side-path to the well documented "sustainable development", which originally referred to ecological sustainability and was later extended to social sustainability. In the words of Katriina Siivonen (2003: 9), culturally sustainable development can at best be identified from the fact that "areas become more pleasant to live in through conscious efforts to preserve their folklore, various branches of the arts, their cultural environment 
and sites of especially value with respect to their cultural history." Siivonen observes that products that are transfixed for the purposes of tourism may prove too static and homogeneous to conform to the heterogeneous everyday world of the locality itself, which will be in a state of constant change. Thus the local people may see in the tourist product something that alienates it from actual life.

Alongside the trend towards conformity with market forces within society and the regional strategies drawn up in attempts to control and even expedite this trend, the European Union's cultural and regional policies encourage the production and support of regional identities than can also be of significance for the regional economy. In the opinion of Siivonen (2008), these macro-level goals originating from administrative sources may be inconsistent with the identities and processes of cultural interaction that exist at the microlevel. She puts forward two central principles which it would be wise to observe when undertaking culturally sustainable regional development work (ibid. 355-356). Firstly, one should be aware of cultural processes at the micro, intermediate and macro-levels and take these into account in the project activity. Especially if one is able to observe the everyday cultural realities at the micro-level and take these as a basis for project work at the intermediate level, it may be possible to achieve good regional development results that satisfy all the parties involved without any notable tensions or problems. Secondly, culturally sustainable regional development work requires that the project work at the intermediate level should take account of the heterogeneous mindscape of the region to a broader extent than simply within the limits of the areas and groups targeted by the project organizations. Both of these principles are questions of the power of definition, as every effort should be made to prevent this power from accumulating in the hands of just a few dominant instances. Respect for these ethical principles also implies that any economic benefits arising from cultural activities should accrue to those whose intellectual, social and material capital was invested in the regional development work.

\section{Future issues}

It may be noted in the spirit of the cultural turn in regional development that culture, with its numerous dimensions and forms of behaviour can produce material and intellectual well-being for the people and communities in a region, or conversely, culture itself may be a charming outcome of comprehensive well-being in a community. The developmental rhetoric is naturally disinclined to foster romantic myths of artists who are on the verge of genius and whose creative powers will respond only to economic deprivation. Unfortunately, however, this is very much closer to the situation in reality for many artists - but without the romantic aspect.

The discourse of creative economics that has come into fashion recently maintains that regions which invest in creative environments and promote tolerance, pluralism and a creative ethos will also fare best economically (see Florida 2005). Although Richard Florida's descriptions of the emergence of a creative class within society are highly optimistic and unrealistic when one considers the areas of Finland that lie outside the actual growth centres, there may be something challenging to be found in this way of speaking and something that obliges those responsible for regional development measures to take action. It would be interesting from a research point of view to find out whether the EU's regional projects or the local authority cultural strategies have actually established a new logic that allows artists and those engaged in creative work in general to make a living 
from this work and whether they have given rise to new value chains either in the growth centres or in the areas outside them.

Another issue that should be addressed is what branches of culture and the arts have cultural strategies and projects sought to support and promote - and what branches or ideas have they perhaps ruled out. There is also a further question of interest concerned with culturally sustainable development: how have its principles been understood and taken into account in cultural strategies and projects? The theories of Bourdieu, Habermas or Putnam could be used as a basis for examining not only communicatively fluent development processes but also instances of social friction, conflicts and cultural struggles. One should not be afraid of analysing power relations, either, even though there may not be much demand for such a study or much use to be made of its results in the context of administrative development work.

Although there are certain risks attached to the administration of cultural and creative fields, it is easy to agree with the observation of Wilenius (2004: 68) regarding society's duty to guarantee the existence of adequate conditions for cultural and creative activities: "Creativity cannot be forced to show itself by means of any programme, but it is possible to prepare the ground for it to arise of its own accord." It is absolutely essential in regional development to be aware of the history, values, ways of speaking and future aspirations attached to the various social fields, and this calls for communicative activity, sensitivity to cultural pluralism and an awareness of the limitations and possibilities of systematic development work on the part of all those involved.

\section{Bibliography and references}

Adorno, Theodor W. 1972: Ästhetische Theorie. Gesammelte Schriften. Band 7. Suhrkamp Verlag, Frankfurt am Main.

Ahponen, Pirkkoliisa 1991: Kulttuuripolitiikka ja sen representaatiot. Tutkimus ylevän maallistumisesta. Joensuun yliopiston yhteiskuntatieteellisiä julkaisuja No 13, Joensuu.

Arnestad, Georg 1992: Kultur som lokaliseringsfaktor. Korleis omplante dei mellomeuropeiske erfaringane til Norden? Foredrag i kulturseminar i Helsingfors 18.2.1992. Vestlandsforskning, Sogndal.

Belfiore, Eleonora 2002: Art as a Means of Alleviating Social Exclusion: Does It Really Work? A Critique of Instrumental Cultural Policies and Social Impact Studies in the UK. International Journal of Cultural Policy 8(1) 2002, 91-106.

Bourdieu, Pierre \& Wacquant, Loïc 1995: Refleksiiviseen sosiologiaan: tutkimus, käytäntö ja yhteiskunta. Joensuu University Press, Joensuu.

Cantell, Timo 1993: Musiikkijuhlien yleisöt. Kaustinen, Kuhmo, Viitasaari. Taiteen keskustoimikunta, Helsinki.

Culture and Local Development. OECD 2005. 
Duelund, Peter (ed.) 1992: Kulturens spændetrøje. Om kultur og kulturforskning I Norden. NordREFO No 1, København.

Duelund, Peter (ed.) 1993: Kulturens brug eller misbrug. Om kultur og regionaludvikling i Norden. Mål, erfaringer, muligheder. NordREFO No 2, København.

E-P-liitto 2004: Kulttuurisesti kilpailukykyinen ja elinvoimainen Etelä-Pohjanmaa Kulttuuristrategia 2005-2013. http://www.epliitto.fi/upload/files/kultstrategia.pdf

Escobar, Arturo 1995: Encountering Development. The Making and Unmaking of the Third World. Princeton University Press, Princeton, New Jersey.

Florida, Richard 2005: Luovan luokan esiinmarssi. Talentum, Helsinki.

Habermas, Jürgen 1981: Theorie des kommunikativen Handelns I \& II. Suhrkamp Verlag, Frankfurt am Main.

Hansen, Trine B. 1993: Kulturens økonomiske beydning. "State of the Art". AKF memo, København.

Heiskanen, Ilkka 1994: Kulttuuripolitiikan linjat. Kansallisen kulttuurin prototyypistä hyvinvointivaltiollisen kulttuuripolitiikan kautta kohti uutta - kenties monikansallista kulttuuria. Hyvinvointikatsaus 2, 6-9.

Himanen, Pekka 2004: Välittävä, kannustava ja luova Suomi. Katsaus tietoyhteiskuntamme syviin haasteisiin. Tulevaisuusvaliokunta, teknologian arviointeja 18. Eduskunnan kanslian julkaisu No 4, Helsinki.

Häyrynen, Simo 2006: Suomalaisen yhteiskunnan kulttuuripolitiikka. SoPhi 99, Jyväskylä.

Ilmonen, Kari 1992: Kulttuuripalvelujen käyttö ja kulttuuriarvostukset. Jyväskylän yliopiston Chydenius-Instituutin tutkimuksia No 5, Kokkola.

Ilmonen, Kari 1994a: Kulttuurin strategiat. Tutkimus keskipohjalaisten kulttuuriarvostuksista. Jyväskylän yliopiston Chydenius-Instituutin tutkimuksia No 1, Kokkola.

Ilmonen, Kari 1994b: Taide ja hyvä kaupunki. Taiteilijatulkintoja. Jyväskylän yliopiston Chydenius-Instituutin tutkimuksia No 4, Kokkola.

Ilmonen, Kari 1998: Kulttuuri alueen käyttövarana. Kulttuuripolitiikan hallitsevat ja marginaaliset diskurssit Keski-Pohjanmaalla. Joensuun yliopiston yhteiskuntatieteellisiä julkaisuja No 32, Joensuu. Dissertation.

Ilmonen, Kari 2003: Soittajille soppaa. Koulutuksen haasteet rytmimusiikissa. Like, Helsinki.

Ilmonen, Kari 2009: Kulttuurin ja aluekehittämisen jännitteet ja mahdollisuudet. In: Yhteiskuntatieteen maailma. Seija Virkkala \& Riitta Koski (Eds.). Vaasan yliopiston opetusjulkaisuja No 59. Aluetiede 5, 80-90. Vaasa. 
Ilmonen, Kari, Kaipainen, Jouni \& Tohmo, Timo 1995: Kunta ja musiikkijuhlat. Kunnallisalan kehittämissäätiö, Helsinki.

Jauhiainen, Jussi S. \& Niemenmaa, Vivi 2006: Alueellinen suunnittelu. Vastapaino, Tampere.

Kainulainen, Kimmo 2004: Elämyksistä elinkeinoja. Kulttuuritapahtumien

paikallistaloudelliset merkitykset maaseutukunnille ja kaupungeille. Maaseudun tutkimus- ja koulutuskeskus. Helsingin yliopisto, Helsinki.

Kainulainen, Kimmo 2005: Kunta ja kulttuurin talous. Tulkintoja kulttuuripääoman ja festivaalien aluetaloudellisista merkityksistä. Tampere University Press, Tampere.

Dissertation.

Kangas, Anita 2004: New Clothes for Cultural Policy. In: Construction of Cultural Policy. Pirkkoliisa Ahponen \& Anita Kangas (Eds). SoPhi 94, 21-39. Jyväskylä.

Koivunen, Hannele 2004: Onko kulttuurilla vientiä? Opetusministeriön ja kauppa- ja teollisuusministeriön Kulttuurivienti-hanke. Selvitysmiehen raportti. Opetusministeriön julkaisuja No 22, Helsinki.

K-P-liitto 2007. Keski-Pohjanmaan maakuntaohjelma 2007-2010. http://www.heinakuu.com/lataa/kp_maakuntaohjelma.pdf

Laurila, Kaarle S. 1947: Estetiikan peruskysymyksiä. WSOY, Helsinki.

Lindeborg, Lisbeth 1991a: Kulturens betydelse. Exemplet Tyskland. ERU-rapport No 68, Stockholm.

Lindeborg, Lisbeth 1991b: Kultur som lokaliseringsfaktor. Erfarenheter från Tyskland. Industridepartementet No 22, Göteborg.

Loisa, Raija-Leena 2004: Cultural Industry as Paradox or Synergy. In: Construction of Cultural Policy. Pirkkoliisa Ahponen \& Anita Kangas (Eds). SoPhi 94, 151-169. Jyväskylä.

Luoto, Ilkka 2006: Paikan tekstit ja narratiivinen jännite - kuusi maaseutukylää Suomessa ja Skotlannissa. Terra (118)3-4 2006, 143-158.

Luoto, Ilkka 2008: Paikan tekstit ja niiden henki. Johdatus semiotiikkaan - matkakertomus paikan kulttuuriseen ytimeen. Oulun yliopisto: Nordia Geographical Publication. Volume 37:2. Dissertation.

Luttinen, Jaana 1997: Fragmentoituva kulttuuripolitiikka. Paikallisen kulttuuripolitiikan tulkintakehykset Ylä-Savossa. Jyväskylä Studies in Education, Psychology and Social Research 126, Jyväskylä. Dissertation.

Merli, Paola 2002: Evaluating the Social Impact of Participation in Arts Activities: a Critical Review of Francois Matarasso's Use or Ornament? International Journal of Cultural Policy 8(1) 2002, 107-118. 
Miles, Steven \& Paddison, Ronan 2005: Introduction: The Rise and Rise of Culture-led Urban Regeneration. Urban Studies 42(5-6) 2005, 833-839.

Myerscough, John 1988: The Economic Importance of the Arts in Britain. Policy Studies Institute, London.

Oakes, Tim 2006: Cultural Strategies of Development: Implication for Village Governance in China. The Pacific Review 19(1) 2006, 13-37.

Paasi, Anssi 1990: Kulttuuri ja alueellinen kehitys. In: Luova ympäristö - luova ihminen. Raportti ensimmäisestä KULTI-seminaarista Oulussa. Ilkka Marjomaa \& Jukka Nykyri (Eds). Oulun yliopiston Täydennyskoulutuskeskuksen julkaisuja No 6, 38-47.

Purontaus, Sampo 2008: Toiveiden tynnyri. Osallisuus Kokkolan kaupungin kulttuuripoliittisessa suunnittelussa. Joensuun yliopiston humanistisia julkaisuja No 54, Joensuu. Dissertation.

Putnam, Robert D. 1993: Making Democracy Work. Civic Traditions in Modern Italy. Princeton University Press, Princeton.

Radcliffe, Sarah A. (ed.) 2006: Culture and Development in a Globalizing World. Geographies, actors and paradigms. Routledge, London \& New York.

Rydman, Jan \& Sappinen, Jorma 1988: Taide ja taloustiede: kvasitiedettä postmodernismin hengessä? Kansantaloudellinen aikakauskirja 83(3) 1988, 315-317.

Siisiäinen, Martti 2003: Yksi käsite, kaksi lähestymistapaa: Putnamin ja Bourdieun sosiaalinen pääoma. Sosiologia 40(3) 2003, 204-218.

Siivonen, Katriina 2003: Mikä on kulttuurisesti kestävää? Kulttuuri arkisena vuorovaikutuksena ja matkailutuotteena. Kulttuurintutkimus (20)2 2003, 9-15.

Siivonen, Katriina 2008: Saaristoidentiteetit merkkien virtoina. Varsinaissuomalainen arki ja aluekehitystyö globalisaation murroksessa. Kansatieteellinen arkisto No 51, Helsinki.

Dissertation.

Sotarauta, Markku \& Kosonen, Kati-Jasmin 2004: Strategiarituaaleja koneistoyhteiskunnassa vai dynaamisia prosesseja tietämystaloudessa. In: Yksilö, kulttuuri, innovaatioympäristö. Avauksia aluekehityksen näkymättömään dynamiikkaan. Markku Sotarauta \& Kati-Jasmin Kosonen (Eds). Tampere University Press, Tampere.

Taide on mahdollisuuksia (TAO) 2002: Ehdotus valtioneuvoston taide- ja taiteilijapoliittiseksi ohjelmaksi. Taide- ja taiteilijapoliittinen toimikunta. Opetusministeriö, Helsinki.

Valtonen, Hannu 1992: Kulttuuri ja kansantalouden edut. Kulttuuritutkimus (9)1 1992, 3-10.

Wilenius, Markku 2004: Luovaan talouteen. Kulttuuriosaaminen tulevaisuuden voimavarana. Sitran julkaisusarja No 266. Edita, Helsinki. 